ISSN: $2576-2141$

\title{
Illicit Drugs and Correctional Institutions: A Case Study of Zenica Penitentiary in Bosnia-Herzegovina
}

\author{
Amer Smailbegovic ${ }^{1}$, Nedzad Korajlic, Marija Lucic-Catic, Muamer Kavazovic \\ University of Sarajevo, Bosnia and Herzegovina \\ Redzo Kahric \\ Zenica Penal-Correctional Institution, Bosnia and Herzegovina
}

\begin{abstract}
The Penal-Correctional Institution of the Enclosed Type in Zenica (Kazneno-popravni zavod zatvorenog tipa Zenica), Bosnia-Herzegovina, has been in continuous operation for over 130 years and is currently the largest and most-diverse penal institution in the country. With 714 inmates serving lengthy sentences (up to 40 years) for the variety of serious offenses (including terrorism), the issue of narcotics use, traffic and trade has been encountered and countered, particularly in the last decade. The types of drugs encountered in the institution range from prescription drugs (i.e. buprenorphine, methadone), to "heavy" narcotics (i.e. heroin, morphine, speed. The type, quantity and frequency of drug use and seizure shows certain seasonal and temporal effects and is associated with the inmate-furlough periods, awarded for good behavior. Many inmates use this privilege to bring narcotics into the facility. Some of the encountered substances have been seized from the facility visitors and even from the prison staff, in the past five years, but the charges have been generally dismissed by the prosecutors for the lack of evidence. An average seizure is about ten grams per incident, and the number of seizures has been continuous, suggesting considerable financial interest and gain for the drugs to enter the institution. There are various measures proposed to counter the traffic and limit the purchases, however the inmate population is very apt in using the current legal regulations and EU-mandates to circumvent the proposed countermeasures. This study is presenting some of the findings, directions and recommendations for combating the drug-traffic within the correctional institution.
\end{abstract}

KEYWORDS: Narcotics, Penal-Correctional Institutions, Zenica, Bosnia-Herzegovina.

\section{Introduction}

Bosnia-Herzegovina inherited most of its incarceration facilities from the AustroHungarian Empire, which were somewhat expended during various incarnations of Yugoslavia; after the break-up of Yugoslavia and Bosnia-Herzegovina statehood in 1992, the correctional facilities have largely fell into overcrowding and disrepair (Twinning Light Project, 2008), compounded by the societal problems encountered in the post 1992-95 hostilities period. The Zenica Penal-Correctional institution is located in the city of Zenica, Bosnia-Herzegovina (pop. 115,334), currently accommodating 714 inmates (designed for 630), with the highest prison sentence served of 40 years. The institution is the only maximum-security incarceration facility in Bosnia-Herzegovina and with the length and severity of sentences, coupled with a variety of

\footnotetext{
${ }^{1}$ Corresponding Author: amersmail@ gmail.com
} 
environmental conditions such as overcrowding, aged buildings, pollution and limited correctional staff, the environment is ripe for drug use.

\section{Background}

The Zenica Correctional Facility was built in the 1886-89 period, during the AustroHungarian Monarchy administration, as the most modern reformatory correctional facility based on the progressive "Irish" system, where the inmates had the opportunity to work, study and reform themselves; as a result, the facility was built with its own industrial base (foundry, farms, workshops) and it was intended to operate as a self-sustained facility. (Mahmutovic, 2014). Currently, the facility is undergoing modernization of the accommodation and permanent organizational facilities but also expansion of the arable land, greenhouses, agricultural farms, bakery and such required for the function of the facility (and budgetary savings). Inmates receive wage amounting to approximately 100 EUR for performing various work within one of the industries of the correctional facility or earn time-off for good behavior. As of 2019, there were 714 inmates serving sentences, (which is down from the all-time high of 850 inmates in 2013). According to the current Criminal and Penal Code of BosniaHerzegovina (Court of Bosnia and Herzegovina, 2003) the serving inmates exhibiting exemplary behavior can be granted a furlough of up to six days per calendar year. Many inmates abuse this privilege to bring illicit substances into the correctional facility or make other supply arrangements (i.e. delivered during visits, or legitimate medical supplies) into the facility for further use and distribution (Lucic-Catic, 2012).

\section{Drug Use in Zenica Correctional Facility}

While all correctional facilities in the former Yugoslavia, have had problems with drugs, Zenica Correctional Facility is a home of the largest inmate population, including many violent offenders (murder, terrorism) and a number of major drug dealers. The particular environment of inmates serving long sentences, coupled with frequent occurrences of snap violence and ability of certain "kingpins" to source contraband from the outside have contributed to Zenica's bad reputation and drug problem (Center for Investigative Reporting, 2008). According to the internal statistics and investigations (Zenica Penal-Correctional Insitution, 2020), the value of the seized narcotics in the facility exceed the street value by five-fold and that the younger prisoners are typically drawn in as mules (or users) by the older inmates, who provide narcotics or controlled substances for free in the beginning as a way to get future customers.

Many of the "exemplary inmates" are easily conscripted to bring in the drugs from the outside upon returning from the furlough, with a benefit of receiving "protection" as well as having a "cut" in the profit, because in accordance with the Penal Code of Bosnia and Herzegovina (Court of Bosnia and Herzegovina, 2003), an inmate who commits a new criminal offense, while serving a sentence of imprisonment, for which the law stipulates one year imprisonment, only a disciplinary measure may be imposed upon such inmate with the maximum sentence being 20 days in solitary confinement. Furthermore, in order to be charged (and convicted) of a trafficking offense, the prosecutors must demonstrate from whom an inmate had obtained a particular narcotic (Pajevic, Kavazovic, \& Lucic-Catic, 2017), and to whom and when he had sold it; in practice, none of the inmates are ever willing to testify (LucicCatic, 2012(b)). Some of the encountered substances have been seized from the facility visitors and even from the prison staff, in the past five years, but the charges have been generally dismissed by the prosecutors due to the lack of evidence and difficulty in prosecuting beyond the simple possession infraction (Court of Bosnia and Herzegovina, 2003). 


\section{Methodology and Data:}

Because of the inherent complexity and restrictions placed upon conducting research within the maximum-security prison in Bosnia and Herzegovina, the information presented is based on the internal annual reviews of the Zenica Penitentiary. The data are not available or releasable to the public without a written approval from the Ministry of Security, Federation of Bosnia-Herzegovina (issued to the authors of this article on January 23, 2020, specifically authorizing the release). The data presented in this article are thus derived from the weekly, monthly and annual facility internal security and auditing service, the tables showing a snapshot of the extent of narcotic and controlled-substance detection, and the interventions carried out in 2018 and 2019. In instances where a substance was found and tested positive for the presence of a controlled or prohibited substance, the table is marked as "positive detect," otherwise it is reported as "negative."

Table 1

Activities carried out within Zenica Penal-Correctional Facility in 2018 and 2019 related to the detection of narcotics and other controlled substance.

\begin{tabular}{|c|c|c|}
\hline \multicolumn{3}{|c|}{2018} \\
\hline Activity Description & No. of Events & Disposition \\
\hline Inmate housing quarters control & 91 & Positive detect \\
\hline Incoming inmate packages / mail & 98 & Positive detect \\
\hline Control and assessment of persons, inmate & 80 & Positive detect \\
\hline Control of vehicles within the facility & 23 & Positive detect \\
\hline External follow-up on information received & 1 & Positive detect \\
\hline Engagement of the narcotics $\mathrm{K} 9$ unit & 218 & 12 Positive detects \\
\hline Other incidents, not inmate related & 50 & Positive detect \\
\hline Substance control and training & 74 & -- \\
\hline \multicolumn{3}{|l|}{ o } \\
\hline Activity Description & No. of Events & Result \\
\hline Inmate housing quarters control & 28 & Positive detect \\
\hline Incoming inmate packages / mail & 90 & Positive detect \\
\hline Control and assessment of persons, inmate & 60 & Positive detect \\
\hline Control of vehicles within the facility & 13 & Negative \\
\hline External follow-up on information received & 1 & -- \\
\hline Engagement of the narcotics $\mathrm{K} 9$ unit & 165 & 12 Positive detects \\
\hline Other incidents, not inmate related & 20 & Negative \\
\hline Substance control and training & 46 & -- \\
\hline
\end{tabular}

Based on the records of search and seizure of the illicit substances found within Zenica correctional facility, the following charge complaints were initiated as a result:

Table 2

Summary of charges initiated as a result of narcotic seizure in the 2018-2019 period.

\begin{tabular}{lccccc}
\hline Year & Possession (1) & $\begin{array}{l}\text { Illegal Item } \\
\text { (2) }\end{array}$ & Assault (3) & $\begin{array}{l}\text { Obstruction } \\
\text { (4) }\end{array}$ & $\begin{array}{l}\text { Officer attack } \\
\text { (5) }\end{array}$ \\
\hline 2018 & 2 & 2 & 8 & 1 & -- \\
2019 & 11 & 2 & 5 & -- & 2 \\
\hline BH & (1) Article 239, & & \\
Federation & (2) Sanction as per institution policy & & \\
Penal & (3) Article 173/174 and Article 54 (if injury sustained) & \\
& (4) Article 358 & & \\
\hline
\end{tabular}


code (5) Article 359 Per (Court of Bosnia and Herzegovina, 2003)

reference

As stated previously, there are considerable difficulties in charging the current inmates with trafficking and intent to distribute illicit substances. The formal charges, presented in the Table 2 (in accordance with the article 238 of the Federation Penal Code) are just a small fraction out of 26 positive detection incidents in 2018, and 22 incidents in 2019, where the substance was detected and seized. There were approximately 165 (2018) and 216 (2019) incidents in total where the substance was suspected but no formal charges could be brought up due to insufficient evidence (Zenica Penal-Correctional Insitution, 2020).

As to types of illicit substances encountered during the ten-year tracking period starting from 2007-2017, the results of seizure quantities and types are shown in the Table 3.

Table 3

Types of illicit substances seized at the Zenica Penal-Correctional Facility in 2007-17 period.

\begin{tabular}{|c|c|c|c|c|c|c|c|c|c|c|c|c|}
\hline \multicolumn{13}{|c|}{ Seized substances (measured in grams) } \\
\hline Type & 2007 & 2008 & 2009 & 2010 & 2011 & 2012 & 2013 & 2014 & 2015 & 2016 & 2017 & Total \\
\hline Heroin & 68.2 & 38.6 & 182 & 27.8 & 13.1 & 12.2 & 9.2 & 1.35 & 0.82 & 4.64 & 0.49 & 358.4 \\
\hline Cocaine & 11.4 & & & & & & & & & & & 11.4 \\
\hline Speed & 11.6 & 0.6 & 9.6 & & & & & & & & 5 & 26.8 \\
\hline Cannabis & 0.2 & 1.8 & & 1 & & 5.55 & & & & 1.07 & 9.61 & 19.23 \\
\hline Hash & & & & & & & & & & & 0.5 & 0.5 \\
\hline Opioids & & & & & & & & & & 5.63 & 2.41 & 8.04 \\
\hline Other & & & & & & & & & & 3.04 & 3.77 & 6.81 \\
\hline
\end{tabular}

\begin{tabular}{|c|c|c|c|c|c|c|c|c|c|c|c|c|}
\hline & & & & & & & & & \multicolumn{3}{|c|}{ Total grams seized } & 431.18 \\
\hline \multicolumn{13}{|c|}{ Seized substances (measured in unit pieces) } \\
\hline Type & 2007 & 2008 & 2009 & 2010 & 2011 & 2012 & 2013 & 2014 & 2015 & 2016 & 2017 & Total \\
\hline Ecstasy & & \multirow{5}{*}{30} & & 10 & & & & \multirow{5}{*}{4} & & & & 10 \\
\hline Methadone & & & 93 & & & & \multirow{4}{*}{42} & & & & 1 & 94 \\
\hline Tramadol & & & & & 30 & & & & & & & 60 \\
\hline Subotex* & & & & & & & & & 5 & 13 & 3 & 67 \\
\hline \multirow[t]{2}{*}{ Other } & & & & & & 26 & & & 8 & 2 & 34 & 70 \\
\hline & & & & & & & & & \multicolumn{3}{|c|}{ Total pieces seized } & 301 \\
\hline
\end{tabular}

*Subotex (Subutex/Suboxone) is a brand of Buprenorphine-type opioid used to treat opioid use disorder

The official numbers for 2018-19 period are unavailable from the penitentiary at the time of the writing of this article, however there are certain noted trends sourced from the information from the Public Health Institution for the Treatment and Prevention of Substanceabuse of the Zenica-Doboj Canton (Gov't of Zenica-Doboj Canton, 2019). Based on the public information in the 2017-2019; see Annual reporting for 2017-2019 within (Gov't of ZenicaDoboj Canton, 2019) and the trends described below on the problematics of the substance-abuse at the Zenica Penal-Correctional Institution:

- In 2019, there were 20 patients undergoing opiate-substitution therapy at the penitentiary; that number is relatively consistent with the number of patients treated in 2017 (17 patients) and 2018 (30 patients).

- The penitentiary was issued with a total dosage of $23,432 \mathrm{ml}$ of methadone in 2018 for the inmates undergoing substitution-therapy.

- Since 2013, a new therapy using Buprenorphine-type therapy (Subutex) was initiated at the penitentiary; the total number of doses issued was 1,421 mg (2018) and 1,366 mg (2017) in the penitentiary.

- The total number of Buprenorphine-type therapies given were 942 (2016), followed by 360 (2017) and 244 (2018). 
- Median dosage of methadone was $63.24 \mathrm{mg} /$ day, and Buprenorphine $8 \mathrm{mg} /$ day (underthe-tongue tablet dose).

- From 178 inmates tested for drugs in 2018, 26 were found positive for drugs upon Discussion returning to the penitentiary (from the furlough).

This is the first recent study carried out on the subject of drug abuse within the correctional system in Bosnia-Herzegovina and it may open a pathway towards more detailed or encompassing studies involving all of the correctional facilities in the country. Because of the complexities related to the data-release as well as complicated system of governance in the Bosnia-Herzegovina the presented results are based on the information released from the PenalCorrectional Institution and the Institute for the Substance-abuse Treatment and Prevention in Zenica, Bosnia-Herzegovina, from 2017-2019. We are noting the following four trends:

1. Starting in 2014 , there is a notable decline in the amount of narcotics intercepted and seized at the Penitentiary, likely resulting from the improvements in the surveillance and detection capabilities (Council of Europe, 2016)

2. Substituting the type of drug-rehabilitation from Methadone-type to Buprenorphinetype (Subutex) in 2013, resulted in the disappearance of Methadone in seizures, starting in 2010-2011 and switch to Subutex in 2013, corresponding with the initiation of the new replacement-therapy initiative (Gov't of Zenica-Doboj Canton, 2019).

3. The overall number of inmates receiving treatment remains somewhere in the $2-3 \%$ percent of the total number of inmates, as per annual reports 2017-2019 (Gov't of Zenica-Doboj Canton, 2019).

4. The peak drug-seizure appear to have been correlated with the overcrowding conditions from 2009-2013 (Council of Europe, 2016). The subsequent renovations and expansion of the facility have apparently reduced the number of incidents reported.

Buprenorphine appears to be the medicament of choice as it is readily available for treatment and can be sourced through the variety of legal loopholes (i.e. straw prescription purchase, sourcing from a rehab patient etc.) and its application versus the number of patients and seizures is shown in the figure below. According to the internal Facility investigations, the in-house prison dealers, divide one (1) gram of the narcotic (usually the replacement-therapy drug Subutex) into 10 to 15 "boots" (Modly, Šuperina, \& Korajlić, 2008) that are packaged and sold at a price of up to 25 EUR, which is roughly 5 times the street value for the drug (Korajlic, 2012). The drug is usually mixed by the dealers with other substances to stretch the quantity or sometimes alter its potency or effects (Korajlic, 2012). The inmates usually pay for drugs with the various pre-paid cards (mainly phone cards ranging in the values of 15-50 EUR) or their facility work monthly remuneration (100 EUR), resulting in the gross profit for the dealer of 150-250 EUR per one gram of pure, uncut narcotic (Center for Investigative Reporting, 2008). According to the reports from the search-and-seizure teams from the penitentiary, the inmates and mules, carrying the narcotic from the outside, prefer Subutex for the ease of concealment and subsequent mixing. According to the Federal regulations (Gov't of the Federation of Bosnia-Herzegovina, 2011) the inmates are required to demonstrate that they have ingested the dose, however many inmates find creative ways to circumvent this requirement. 


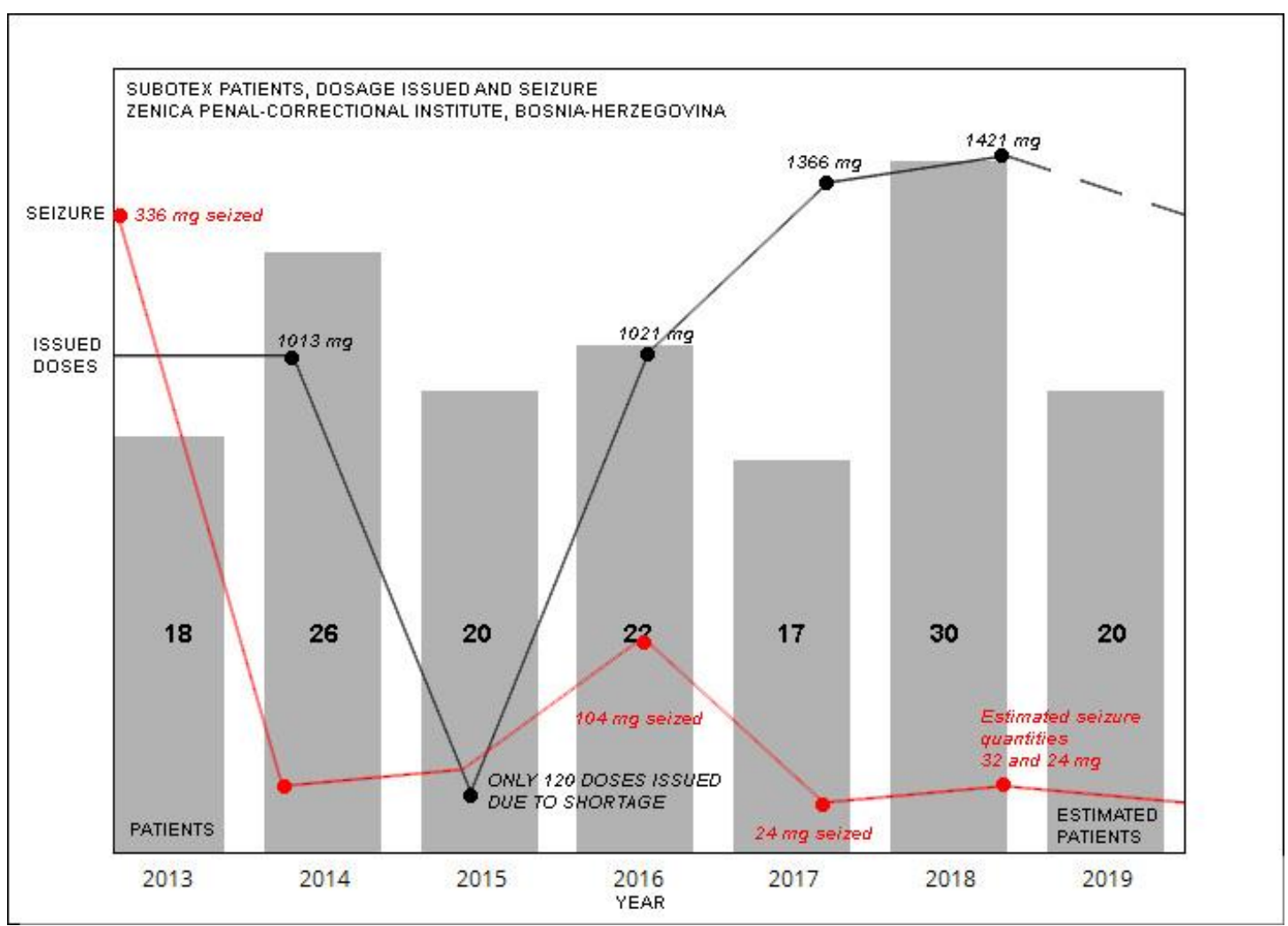

Figure 1. Patients undergoing the substitution therapy in Zenica Penal-Correctional Institution versus the number of dosages of Subutex (Buprenorphine) issued and their annual seizures. Note that the Subutex-based therapy started in 2013; Subutex is more potent and given in a smaller dose than Methadone, hence the seizure amount (in grams) is proportionally smaller.

To combat the proliferation of narcotics, the penitentiary has increased the videosurveillance capabilities, SIM-card and phone-detection and jamming equipment, GPSmonitoring of the furloughed inmates as well as reduction in the number of inmates per prison section, increasing the number of wardens and monitors and assigning a special drug-counselor to the groups of 50 serving inmates. These measures have been implemented since 2016, which is demonstrated by the increased level of drug detection, seizure and issuance of appropriate sanctions. There are also current programs (Council of Europe, 2018) to revise policies on how the inmates are paid and how they can use their communication privileges (i.e. phone-cards) so that they cannot be used as a form of currency that enables drug and/or other illicit trade.

\section{Conclusions}

Zenica Penal-Correctional Institution is well aware of the drug problem and is actively taking steps to counter their entry and proliferation within the inmate population. Currently (2020), the facility is understaffed, relatively overcrowded and often ensnared in various media exposure or political ramifications, stemming from its size, reputation and housing of the worst criminals in Bosnia-Herzegovina. Based on the data presented within this limited scope, there are apparent reductions in the number of drug-related incidents within the facility. The main drugs of choice are the drug-replacement therapy medications that can be prescription-sourced and then used as an opiate-base within the institution. Better living-conditions, prison engagement programs, surveillance and inmate-separation policy (as the facility is gradually expanded) are expected to create better conditions for countering the availability and proliferation of drugs within the penitentiary. We are hoping that this article will encourage additional research and comparative analysis with the other penal-correctional institutions in Bosnia-Herzegovina (and other former Yugoslav states). 


\section{References}

Center for Investigative Reporting. (2008, April 7). Inmates Becoming Heroin Addicts. Sarajevo, Bosnia and Herzegovina.

Council of Europe. (2016). Report to the Government of Bosnia and Herzegovina on the visit to Bosnia and Herzegovina carried out by the European Committee for the Prevention of Torture and Inhuman or Degrading Treatment or Punishment (CPT) from 29 September to 9 October 2015. Strasbourg: Council of Europe.

Council of Europe. (2018, 9 10). Joint programme, Prison Reform Programme in BosniaHerzegovina. Retrieved from European Union, Council of Europe: https://pjpeu.coe.int/en/web/bih-prison-reform-programme/home?desktop=true

Court of Bosnia and Herzegovina. (2003). Penal Code of Bosnia and Herzegovina of 27 June 2003 (3/03) (Text No. 292), revised 5/2018. Official Gazette of Bosnia and Herzegovina, 2003-11-22, 37, 867-900.

Gov't of the Federation of Bosnia-Herzegovina, 2011 (rev.) Criminal Sanctions Law.

Official Gazette of Bosnia and Herzegovina nos. 44/1998, 42/1999 - revised, 12/2009 and 42/2011)

Gov't of Zenica-Doboj Canton. (2019). Year-end report for the operation of the Public Insitution for Substance-Abuse Treatment. Zenica: Government of Zenica-Doboj Canton, Federation of Bosnia and Herzegovina.

Korajlic, N. (2012). Narko-kriminalitet (Narco-criminal). In N. Korajlic, Istrazivanje Krivicnih Djela (Investigating Criminal Acts) (p. 711). Sarajevo: Pravni Fakultet (Faculty of Law).

Lucic-Catic, M. (2012). Challenges in conducting prison research. Journal of Criminal Justice Issues (Kriminalisticke teme), 11.

Lucic-Catic, M. (2012 (b)). Kriminalisticke procedure istrazivanja krivicnih djela zatvorenika (Criminalistic investigative procedures of criminal acts committed by serving inmates). In N. Korajlic, Istrazivanje Krivicnih Djela (Investigating Criminal Acts) (p. 844). Sarajevo: Pravni Fakultet (Faculty of Law).

Mahmutovic, V. (2014). Robijaši KPD Zenica 1918. do 1941. godine (Convicts of Zenica Correctional Facility 1918-1941). Tesanj: Planjax Group Tesanj.

Modly, D., Šuperina, M., \& Korajlić, N. (2008). Rječnik kriminalistike (Criminalistic Dictionary). Zagreb: Strukovna udruga krminalista (Professional Society of Criminalistics).

Pajevic, D., Kavazovic, M., \& Lucic-Catic, M. (2017). Relationship of Prosecutors and Expert Witnesses in Legal System of Bosnia and Herzegovina: Forensic Expertise-An Evidence That Is in the Ascendant. JE-Eur. Crim. L., 157, 49-53.

Twinning Light Project. (2008). Final Report: Support to the Penitentiary Management Report in Bosnia and Herzegovina. Wien, Austria: Federal Ministry of Justice of Austria, Center for Legal Competence (CLC).

Zenica Penal-Correctional Insitution. (2020). Report on drug use within facility. Zenica: Written communication tothe Faculty of Criminalistics and Security Studies, Sarajevo, 04-49-3644/19.

Manuscript received February 28, 2020

Final revision received April 20, 2020

Accepted April 23, 2020 